\title{
Drywall Waste Blocks: \\ A Novel Masonry Material Utilizing Recycled Construction \& Demolition Waste
}

\author{
David Drake $^{1 *}$, Fadil Zaky Ramadhan ${ }^{2}$, Ping Fai Sze ${ }^{3}$, and Taiji Miyasaka ${ }^{4}$ \\ ${ }^{1}$ Adjunct Professor, School of Design and Construction, Washington State University \\ ${ }^{2}$ M.Arch Candidate, School of Design and Construction, Washington State University \\ ${ }^{3}$ M.Arch Candidate, School of Design and Construction, Washington State University \\ ${ }^{4}$ Professor, School of Design and Construction, Washington State University \\ "Corresponding author's e-mail: mrdrake@wsu.edu
}

\begin{abstract}
This paper describes patent-pending mixtures and methods for producing masonry blocks using gypsum drywall waste and preliminary investigation of Drywall Waste Block (DWB) engineering properties. Recycling waste from building construction and demolition (C\&D) provides many environmental and economic benefits. However, challenges remain for recycling certain low-value C\&D materials, such as gypsum drywall waste, and there are few uses for drywall waste from demolition, which constitutes the majority of the drywall waste stream. Recycling drywall waste is desirable as this waste produces noxious hydrogen sulphide gas in landfill conditions, resulting in bans on landfilled drywall waste in some localities. Investigation of compressive strength, water absorption, and thermal performance of DWB specimens is described, and results are compared to specifications for concrete masonry units (CMU), and other comparable masonry blocks. Technical gaps for DWB to be recognized as a CMU alternative are also discussed.
\end{abstract}

\section{KEYWORDS}

Construction \& demolition waste; Drywall recycling; Drywall waste blocks; New technologies $\&$ materials; Blast furnace slag; Insulative masonry systems

\section{INTRODUCTION}

Waste from building construction and demolition (C\&D) is a growing problem (EPA 2016). Industry studies show recycling $C \& D$ waste provides environmental and economic benefits (CDRA 2017). However, challenges remain for recycling some C\&D waste materials, especially when recycled wastes have limited use and low value (CDRA 2017; King County 2017).

Gypsum drywall (known as drywall, plasterboard, and the trade name Sheetrock) is widely used for residential and commercial interiors. In 2017, an estimated 2.3 billion $\mathrm{m}^{2}$ ( 25 billion $\mathrm{ft}^{2}$ ) of drywall was sold in the United States alone (Crangle 2018). Drywall is fire resistant, inexpensive, and relatively easy to install. Drywall panels consist of a gypsum $\left(\mathrm{CaSO}_{4} \cdot 2 \mathrm{H}_{2} \mathrm{O}\right)$ core, sandwiched between paper facing and backing layers, modified with various admixtures. 
Installation methods minimize joints between panels to reduce finishing costs, but produce significant waste: typically 10-12\% of installed material (Crangle 2017). Building demolition generates more than three times the volume of drywall waste from construction (EPA 2016).

Historically, drywall waste has been disposed of in municipal landfills, comingled with other C\&D wastes. In 2016, the most recent year for which figures are available, 8.8 million metric tons (9.7 million short tons) of drywall waste was landfilled in the United States, approximately 9.1\% of all landfilled waste from building C\&D (CDRA 2017). Under landfill conditions, sulphur-reducing bacteria metabolize drywall waste and produce hydrogen sulphide gas $\left(\mathrm{H}_{2} \mathrm{~S}\right)$. Trace amounts of $\mathrm{H}_{2} \mathrm{~S}$ result in offensive 'rotten-egg' odours, and higher concentrations impact human health (Townsend et al. 2002). To mitigate this, diversion of drywall waste from landfills through expanded recycling has been proposed (Lederman et al. 2015), and some localities have banned drywall waste from landfills (Lederman et al. 2015; King County 2017).

There are limited uses for recycled construction drywall waste. Due to inconsistency and concerns over contamination, virtually all drywall waste from demolition is landfilled (CDRA 2017). Lack of demand for recycled drywall waste is a barrier to increased recycling (Lederman et al. 2015). Drywall recyclers have unused capacity, and would like new markets, requiring new applications for recycled waste (CDRA 2017; King County 2017).

Investigation of recycled drywall waste for building materials is reported in literature. Benefits of reducing landfilled waste and substituting waste-derived binders for Portland cement are cited. Naik et al. (2011) investigated use of drywall waste as a supplemental cementitious binder in concrete. Raghavendra and Udayashankar (2015) reported use of drywall waste as a binder component in controlled low strength materials (CLSM). Raghavendra et al. (2016) investigated CLSM ternary binder mixtures of drywall waste, Portland cement, and waste-derived pozzolans. As with current recycling practices, mixtures proposed to-date utilize only gypsum cores, and require removal of facing and backing paper.

This paper reports development and investigation of novel drywall waste mixtures, formed under pressure into hollow-core drywall waste blocks (DWB). DWB mixtures incorporate a higher percentage of drywall waste than other mixtures in literature, and simplify waste processing by comingling core and paper layers in the final product. DWB mixtures utilize demolition and construction waste, replacing a high percentage of Portland cement with waste-derived binder. 


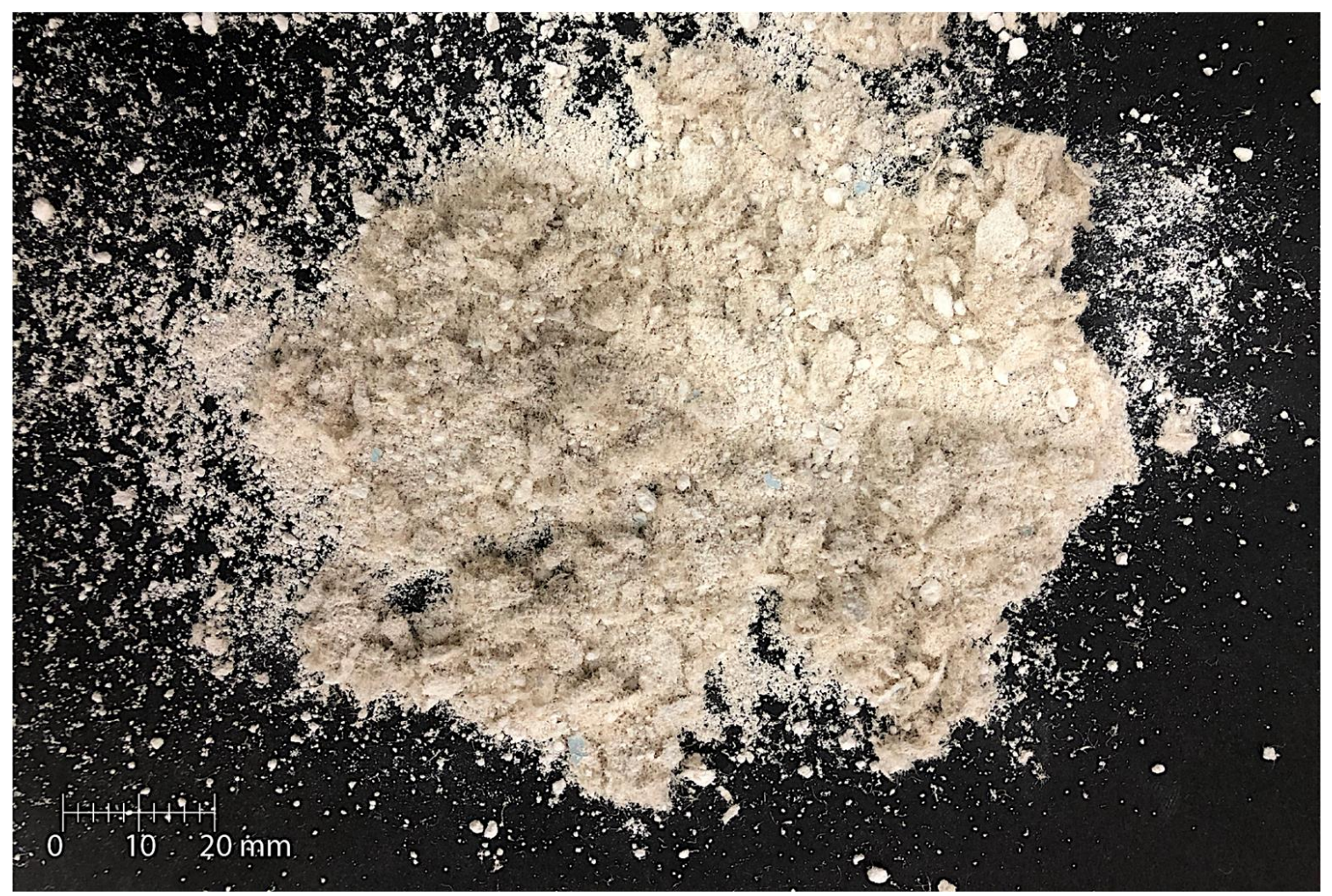

Figure 1. Gypsum drywall waste processed with hammer mill.

\section{METHODS \\ Materials}

Gypsum drywall waste (GW) of 3/8", 1/2", and 5/8" nominal thickness (apx. $9.5 \mathrm{~mm}, 13 \mathrm{~mm}$, and $16 \mathrm{~mm}$ ) was sourced from local building construction and demolition sites. Waste included a variety of drywall types. Demolition waste tested negative for presence of asbestos. Waste was processed using a hammer mill equipped with $5 \mathrm{~mm}$ screen (Figure 1). Old newspaper (ONP) was sourced from Washington State University Recycling Services, also processed using a hammer mill equipped with $5 \mathrm{~mm}$ screen. Portland cement (PC) (ASTM C150 Type I-II) was purchased from local dealer. Ground granulated blast furnace slag (GGBS) (ASTM C989 Grade 100) was supplied by LaFarge North America, manufactured in Seattle, WA from slag sourced from JFE Mineral Company, Kurashiki City, Japan. Asphalt emulsion (AE) was purchased from local dealer, sold as driveway and foundation sealer distributed by the Henry Company.

\section{Mixing and forming}

Aggregates and binders were dry-mixed three minutes in 120 L capacity pan mixer, followed by addition of water in distributed fine spray while mixing, until mix achieved consistency of barely-damp soil, holding shape when squeezed in the hand, without releasing moisture. Mixing continued 10 minutes after water addition.

First-generation block prototypes, measuring $305 \mathrm{~mm}$ x $152 \mathrm{~mm}$ x $76 \mathrm{~mm}$ (12" x 6" x 3"), with two hollow cores each $89 \mathrm{~mm}$ dia. (3.5"), were formed on a custom-made press at $2.3 \mathrm{MPa}$ (340 
psi) pressure, with approximate dry density of $1.0 \mathrm{~g} / \mathrm{cm}^{3}$. Recipe was adjusted until cured blocks exhibited uniform compaction, with no evidence of dissolution when soaked in water. A secondgeneration press was designed and fabricated to produce block prototypes at forming pressure up to $7.6 \mathrm{MPa}(1100 \mathrm{psi})$, with block dry density of approximately $1.2 \mathrm{~g} / \mathrm{cm}^{3}$.

To facilitate testing, cylindrical test specimens with diameter $79 \mathrm{~mm} \pm 0.5 \mathrm{~mm}(\sim 3.1$ in) and height $89 \mathrm{~mm} \pm 2 \mathrm{~mm}(\sim 3.5 \mathrm{in})$ were fabricated using a mould insert. Forming pressure was 7.5 MPa (1090 psi). Specimens were placed in polyethylene bags for initial curing at ambient lab temperature $\left(20^{\circ} \mathrm{C} \pm 5^{\circ} \mathrm{C}\right)$ for seven days, and then removed from bags for curing in air. Dry density of specimens measured at 42 day post-formation ranged from $1.20-1.23 \mathrm{~g} / \mathrm{cm}^{3}$.

\section{Test specimen mix proportions}

Test cylinders of mixes with variable proportions of blast furnace slag were evaluated for unconfined compressive strength (Table 1). Ratio of GW and ONP with respect to total dry mass was held constant. Ratio of aggregate to binder was held constant. Mixing water was added until phenomenology specified above was achieved.

Test cylinders of mixes with variable proportions of asphalt emulsion were evaluated for water absorption (Table 2). PC binder, GW aggregate, and total water content (including water content of asphalt emulsion) were held constant.

\section{Engineering properties}

Unconfined compressive strength of specimens was tested using procedures adapted from ASTM C39/C39M-18, on a modified H-frame hydraulic press equipped with Transducer Techniques LB-20K load cell, 89kN (20,000 lb-f) capacity and Omega DP41-S meter. Specimens were tested at $7,14,28$, and 56 days post-formation.

Water absorption was tested using procedures adapted from ASTM C140/C140M-18. Specimens were air-dried $\sim 28$ days at ambient lab temperature $\left(20^{\circ} \mathrm{C} \pm 5^{\circ} \mathrm{C}\right)$. Half the specimens were dried further in a ventilated oven at $99^{\circ} \mathrm{C} \pm 2{ }^{\circ} \mathrm{C}\left(211^{\circ} \mathrm{F}\right)$ for 24 hours before testing. All specimens were then immersed in water for 24 hours, removed and weighed, and then dried again in a ventilated oven as above, for minimum 24 hours before reweighing. Percentage of water absorbed during immersion was calculated according to the formula in ASTM C140/C140M-18.

Table 1. Mix proportions for unconfined compressive strength test cylinders.

\begin{tabular}{lcccccc}
\hline Mix ID & $\begin{array}{l}\text { GGBS } \\
\text { per cent } \\
\text { of binder }\end{array}$ & GGBS g/100 g & PC g/100 g & $\begin{array}{l}\text { GW } \\
\text { g/100 g }\end{array}$ & ONP g/100 g & $\begin{array}{l}\text { Water } \\
\mathrm{g} / 100 \mathrm{~g}\end{array}$ \\
\hline GBS-00 & 0 & 0 & 15 & 60 & 2 & 23 \\
GBS-25 & 25 & 4 & 11 & 59 & 2 & 24 \\
GBS-50 & 50 & 8 & 8 & 60 & 2 & 23 \\
GBS-75 & 75 & 11 & 4 & 59 & 2 & 23 \\
GBS-90 & 90 & 14 & 2 & 59 & 2 & 24 \\
GBS-100 & 100 & 15 & 0 & 58 & 2 & 25 \\
\hline
\end{tabular}

Note: Drywall waste : binder(s) ratio held constant at 4:1, all mixes. 
Table 2. Mix proportions for water absorption test cylinders.

\begin{tabular}{lccccc}
\hline Mix ID & $\begin{array}{l}\text { Admixture per } \\
\text { cent of total } \\
\text { dry weight }\end{array}$ & $\begin{array}{l}\text { Drywall waste } \\
\text { (DW) g/100g }\end{array}$ & $\begin{array}{l}\text { Portland cement } \\
\text { (PC) g/100g }\end{array}$ & $\begin{array}{l}\text { Asphalt emulsion } \\
(\mathrm{AE}) * \mathrm{~g} / 100 \mathrm{~g}\end{array}$ & $\begin{array}{l}\text { Water } \\
\mathrm{g} / 100 \mathrm{~g}\end{array}$ \\
\hline $\mathrm{AE}-00$ & 0 & 64 & 16 & 0 & 20 \\
$\mathrm{AE}-05$ & 4 & 60 & 16 & 5 & 19 \\
$\mathrm{AE}-10$ & 9 & 56 & 16 & 10 & 17 \\
$\mathrm{AE}-20$ & 19 & 49 & 16 & 21 & 14 \\
\hline
\end{tabular}

Note: Binder content held constant, all mixes.

*Asphalt emulsion $\mathrm{g} / 100 \mathrm{~g}$ equals solids plus water content.

A $305 \mathrm{~mm}$ x $305 \mathrm{~mm}$ x $54 \mathrm{~mm}$ specimen of the GBS-00 mix, pressed at approximately $2.8 \mathrm{MPa}$ (400 psi), was tested for resistance to thermal conductivity using a guarded hot-plate testing apparatus by the Composite Materials and Engineering Center at Washington State University.

\section{RESULTS AND DISCUSSION}

Both generations of DWB prototypes are similar to earth and concrete masonry blocks in appearance, form-factor, and ease of manufacture. Density of DWB is significantly lower than ASTM C90-16a specifications for lightweight CMU, suggesting superior performance with regard to transportation and labour costs.

DWB test specimens with a mixture of GGBS and PC showed higher compressive strength than specimens containing GGBS or PC alone. Strength curves flattened or fell between 28 and 56 days (Figure 2). Compressive strength for all mixtures (Table 3) was below $13.8 \mathrm{MPa}$ (2000 psi) specified for CMU in ASTM C90-16a, but higher than specifications for lightweight, insulative concrete masonry blocks such as autoclaved aerated concrete (ASTM C1386-07), and higher than code-required strengths for earth-masonry systems (ICC 2012).

Table 3. Strength results for GBS series.

\begin{tabular}{|c|c|c|c|c|c|c|}
\hline \multirow[t]{3}{*}{ Mix ID } & \multirow{3}{*}{$\begin{array}{l}\mathrm{H} 2 \mathrm{O} \\
\text { (percent) }\end{array}$} & \multirow{3}{*}{$\begin{array}{l}\text { GGBS binder } \\
\text { (percent) }\end{array}$} & \multicolumn{4}{|c|}{ Experimental values } \\
\hline & & & \multicolumn{4}{|c|}{ Average Compressive Strength, MPa } \\
\hline & & & 7 days & 14 days & 28 days & 56 days \\
\hline GBS-00 & 23 & 0 & 3.05 & 6.24 & 8.70 & 9.01 \\
\hline GBS-25 & 24 & 25 & 3.32 & 7.52 & 9.88 & 10.4 \\
\hline GBS-50 & 23 & 50 & 3.40 & 7.76 & 9.85 & 10.5 \\
\hline GBS-75 & 23 & 75 & 3.43 & 7.82 & 10.5 & 10.5 \\
\hline GBS-90 & 24 & 90 & 3.05 & 6.59 & 10.7 & 9.71 \\
\hline GBS-100 & 25 & 100 & 1.92 & 5.21 & 9.30 & 8.53 \\
\hline
\end{tabular}

Note: Average of 5 specimens, each series. 


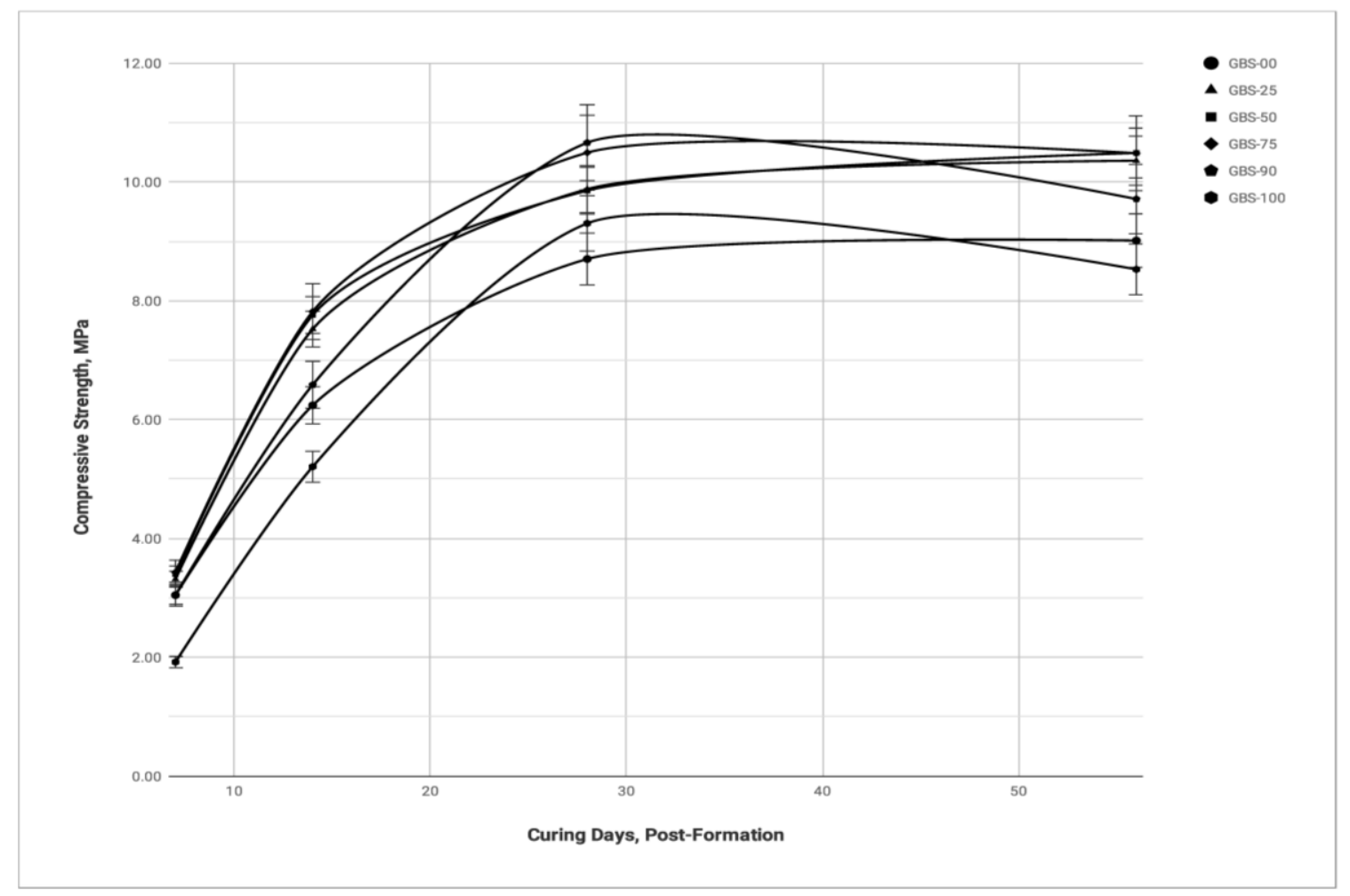

Figure 2. Unconfined compressive strength test results.

DWB specimens tested for water absorption exceeded $20 \%$ maximum specified in ASTM C9016a for CMU (Table 4). However, specimens oven-dried before water immersion showed decrease in dry weight after the second oven drying. Drying temperatures may have caused partial calcination of the gypsum, affecting results.

Resistance to thermal conductivity for the specimen tested ranged from $0.266 \mathrm{~m}^{2} \mathrm{~K} / \mathrm{W}$ ( $\mathrm{R} 1.51$ ), to $0.251 \mathrm{~m}^{2} \mathrm{~K} / \mathrm{W}$ (R 1.43), $54 \mathrm{~mm}$ thickness, for six pairs of temperature differentials, from $25^{\circ} \mathrm{C}$ to $-25^{\circ} \mathrm{C}$. This exceeds published value for lightweight CMU single wythe wall (empty cores) of $0.07 \mathrm{~m}^{2} \mathrm{~K} / \mathrm{W}$ (R 0.32), at $203 \mathrm{~mm}$ (8”) nominal thickness (NCMA 2013).

\section{CONCLUSION}

Qualitative assessment of DWB prototypes supports continued investigation as a replacement for CMU. DWB have potential to divert more gypsum wallboard waste from landfills than methods reported in literature, and require less Portland cement than CMU, resulting in lower embodied energy and smaller carbon footprint. Washington State University has filed for patent protection of mixtures and methods disclosed above (July 2018). 
MOC SUMMIT / MAY 2019

Table 4. Water absorption results for AE series.

\begin{tabular}{llllll}
\hline Mix ID & $\begin{array}{l}\text { Admixture } \\
\text { (per cent) }\end{array}$ & \multicolumn{4}{l}{ Experimental values } \\
\cline { 3 - 6 } & & $\begin{array}{l}\text { OD Initial } \\
\text { weight }(\mathrm{g})\end{array}$ & $\begin{array}{l}\text { Saturated } \\
\text { weight }(\mathrm{g})\end{array}$ & $\begin{array}{l}\text { OD Final } \\
\text { weight }(\mathrm{g})\end{array}$ & $\begin{array}{l}\text { Absorption } \\
\text { (per cent) }\end{array}$ \\
\hline AE-00 & 0 & 494 & 660 & 484 & 36.3 \\
AE-05 & 4 & 484 & 700 & 481 & 45.5 \\
AE-10 & 8 & 501 & 690 & 496 & 39.0 \\
AE-20 & 19 & 494 & 594 & 470 & 26.5 \\
\hline
\end{tabular}

Note: Average of 5 specimens, each series.

Technical gaps remain, including: low compressive strength relative to CMU; higher water absorption than $\mathrm{CMU}$; and reduced compressive strength for some mixtures at longer curing times. Some test equipment and investigation procedures were nonstandard, and ASTM test procedures (e.g., oven drying at specified temperatures) may need to be modified. Measures of compressive strength and water absorption may not be conclusive. Nevertheless, initial results suggest DWB have compressive strength significantly higher than other insulative masonry materials, and higher resistance to thermal conductivity than lightweight CMU.

Areas for future work include: further investigation of admixtures to mitigate water absorption; investigation of whole wall assemblies for resistance to thermal conductivity; investigation of block prisms for compressive strength; and investigation of whole wall assemblies for resistance to sheer forces.

\section{ACKNOWLEDGEMENTS}

Research was supported by an AIA Upjohn Research Initiative Grant and an Amazon Catalyst Fellowship. The researchers gratefully acknowledge assistance from Vikram Yamada (WSU Composite Materials and Engineering Center); Robert Richards (WSU Voiland College of Engineering and Architecture); as well as past and present WSU architecture students.

\section{REFERENCES AND CITATIONS}

Advancing sustainable materials management: 2014 fact sheet. (2016). United States Environmental Protection Agency (EPA), Washington, DC.

ASTM International. (2018). "Standard test method for compressive strength of cylindrical concrete specimens." C39/C39M-18, West Conshohocken, PA.

ASTM International. (2018). "Standard test methods for sampling and testing concrete masonry units and related units." C140/C140M-18, West Conshohocken, PA.

ASTM International. (2017). "Standard specification for loadbearing concrete masonry units." C90-16a, West Conshohocken, PA.

ASTM International. (2007). "Standard specification for precast autoclaved aerated concrete (AAC) wall construction units." C1386-07 [withdrawn], West Conshohocken, PA. 
Benefits of construction and demolition debris recycling in the United States. (2017). Construction \& Demolition Recycling Association (CDRA), Chicago, IL.

Construction and demolition debris generation in the United States, 2014. (2016). United States Environmental Protection Agency (EPA), Washington, DC.

Crangle, R. (2018). "Gypsum." U.S. Geological Survey Mineral commodity summaries, January 2018. USGS, Washington, DC, 74-75.

Crangle, R. (2017). "Gypsum.” U.S. Geological Survey 2015 Minerals yearbook. USGS, Washington, DC, 33.1-33.10.

ICC (International Code Council). (2012). "Chapter 21: Masonry." International Building Code 433-440, Falls Church, VA.

King County LinkUp Program 2017 Market Assessment. (2017). King County Dept. of Natural Resources and Parks Solid Waste Division, Seattle, WA.

Lederman, P., Gannon, J., and Young, L. 2015. Management of Waste Wallboard. New Jersey Dept. of Environmental Protection Science Advisory Board, Trenton, NJ.

Naik, T.R., Kumar, K., Chun, Y and Kraus, R.N. (2010). "Utilization of powdered gypsumwallboard in concrete." Proc. International Conference on Sustainable Construction Materials and Technologies.

NCMA (National Concrete Masonry Association). (2013). R-values and u-factors of single wythe concrete masonry walls. NCMA TEK 6-2, Herndon, VA.

Raghavendra, T., Siddanagouda, Y.H., Jawad, F., Adarsha, C.Y. and Udayashankar, B.C. (2016). "Performance of ternary binder blend containing cement, waste gypsum wall boards and blast furnace slag in CLSM." Proc. International Conference on Sustainable Design, Engineering and Construction.

Raghavendra, T. and Udayashankar, B.C. (2015). "Engineering properties of controlled low strength materials using flyash and waste gypsum wall boards." Construction and Building Materials, 101, 548-557.

Townsend, T., Chadik, P., Bitton, G., Booth, M., Lee, S. and Yang, K. (2002). Gypsum Drywall Impact on Odor Production at Landfills: Science and Control Strategies. Florida Center for Solid and Hazardous Waste Management, Gainesville, FL. 